14 Pensky, J., Hinz, C. F., jun., Todd, E. W., Wedgwood, R. J., Boyer, J. T., and Lepow, I. H., J. Immun., 100, 142-158 (1968), 15 Okuda, T., Yoshioka, Y., Ikekawa, T., Chihara, G., and Nishioka, K., Nature new Biol., 238, 59-60 (1972).

${ }^{16}$ Hamuro, J., and Chihara, G., Nature, 245, 40- 41 (1973).

\section{Liposomes as immunological adjuvants}

ADJUVANTs are widely used to increase antibody formation in experimental animals, for example, Freund's incomplete adjuvant, a water-in-oil emulsion containing the antigen, and Freund's complete adjuvant, which is the same but with killed tubercle bacilli. These adjuvants cannot be used in man because the mineral oil base is not degraded and persists at the injection site. Particularly with the complete adjuvant, unacceptable granulomas can be formed. There is real need for a safe and effective adjuvant for use in human immunisation programmes.

Such an adjuvant could reduce the amounts of antigens, which is administered to humans, can be conveniently labelled with radioactive iodine and is readily incorporated into liposomes; the formation of antibodies can be measured easily by passive haemagglutination. Representative observations in mice immunised with free and liposome-entrapped DT by the intravenous and subcutaneous routes are presented in Table 1. DT administered intravenously in negatively-charged liposomes elicits the formation of much higher concentrations of antibodies than are elicited by free antigen. Subcutaneous (footpad) inoculation of DT in negatively-charged liposomes elicits significantly higher primary and secondary antibody responses than inoculations of the same doses of free antigen. In contrast, antigen entrapped in positively-charged liposomes elicits less antibody than the same dose of free antigen.

Intramuscular injection of DT in negatively-charged liposomes again elicits significantly higher antibody levels than free DT (Table 1). In these and other experiments, dicetylphosphate-containing liposomes as adjuvants were superior to those containing phosphatidic acid. When immune mice were inoculated intravenously with free DT they developed severe

Table 1 Serum antibody responses of mice to diphtheria toxoid administered free or in liposomes of different compositions

\begin{tabular}{|c|c|c|c|c|c|c|}
\hline $\begin{array}{l}\text { Experimental } \\
\text { group }\end{array}$ & $\begin{array}{l}\text { No. of } \\
\text { mice }\end{array}$ & $\begin{array}{c}\text { Mode of } \\
\text { administration }\end{array}$ & $\begin{array}{c}\text { Route of } \\
\text { adminstration }\end{array}$ & $\begin{array}{c}\text { Primary } \mathrm{Ab} \\
\text { resopnse }\end{array}$ & $\begin{array}{c}\text { Secondary } \mathrm{Ab} \\
\text { response }\end{array}$ & Probability \\
\hline $\mathrm{a}$ & 15 & Free & Intravenous & 1.8 & - & a $v$ b,$P<0.01$ \\
\hline $\mathrm{b}$ & 15 & -Liposomes (PA) & Intravenous & 10.0 & - & \\
\hline c & 6 & Free & Subcutaneous & 2.5 & 11.6 & c $v \mathrm{~d}, P<0.01$ \\
\hline d & 6 & -Liposomes (PA) & Subcutaneous & 6.7 & 13.3 & $\mathrm{~d} v \mathrm{e}, P<0.01$ \\
\hline e & 6 & + Liposomes & Subcutaneous & 0 & 11.3 & c $v$ e, $P<0.10$ \\
\hline $\mathrm{f}$ & 6 & Free & Intramuscular & 1.7 & 7.5 & f $v$ g, $P<0.10$ \\
\hline $\mathrm{g}$ & 6 & -Liposomes (PA) & Intramuscular & 3.7 & 11.0 & g $v \mathrm{~h}, P<0.05$ \\
\hline $\mathrm{h}$ & 6 & - Liposomes (DP) & Intramuscular & 6.6 & 12.0 & f $v \mathrm{~h}, P<0.01$ \\
\hline
\end{tabular}

Mice were of the TO strain, except in groups c-e, which were of the CBA strain. Positive $(+)$ liposomes $(0.5 \mathrm{mg}$ lipid) were composed of egg lecithin, cholesterol and stearylamine in molar ratios $7: 2: 1$; in negative $(-)$ liposomes phosphatidic acid (PA) or dicetylphosphate (DP) replaced stearylamine. Primary serum antibody responses were measured after 13 or $14 \mathrm{~d}$, booster injections with $20 \mu \mathrm{g}$ antigen in the same form were given and secondary responses were measured after a further $10 \mathrm{~d}$ (groups c-e) or $14 \mathrm{~d}$ (groups $\mathrm{f}-\mathrm{h}$ ). Antibody responses were measured by indirect haemagglutination (ref. 4) and expressed as the $\log _{2} \mathrm{IH}$ titre.

for example, diphtheria and tetanus toxoids, required for immunisation, with corresponding economies especially relevant to the developing countries. Live virus vaccines have hazards such as the potential initiation of persistent infections or malignancy, and vaccines containing killed viruses or viral antigens often require adjuvants to elicit the formation of protective antibodies. Another possible danger of the use of adjuvants is that in a minority of recipients they may induce allergic reactions to the vaccines which they contain, especially if antigens are administered twice to boost immunity, or if the recipients are already sensitised to an antigen at the time of its administration. It would be an advantage if the mode of presentation of antigens in the adjuvant were such as to avoid allergic reactions. If adjuvants consist of immunogenic materials such as glycolipids or proteins, even in trace amounts, they might themselves induce allergic or even autoallergic reactions through sharing of antigens with those of the recipient or some other mechanism.

We report here the use of liposomes, concentric spheres consisting of phospholipid bilayers separated by aqueous compartments, as immunological adjuvants. Protein and other antigens can be entrapped in liposomes, which have been proposed as carriers of therapeutic agents ${ }^{1,2}$, and we have found that under certain conditions the administration of antigens so entrapped elicits the formation of more antibodies than are elicited by the same doses of free antigen. Liposomcs can be made of non-immunogenic, biodegradable materials and their composition and properties such as electric charge can be varied at will. If animals which already have antibodies are challenged with antigens entrapped in liposomes they are much less likely to develop antibody-mediated allergic reactions than when challenged with the same doses of free antigens ${ }^{3}$.

Diphtheria toxoid (DT) was studied because it is an antigen serum sickness reactions, and the majority died. In contrast, the same amount of antigen inoculated subcutaneously or intravenously did not elicit Arthus or serum sickness reactions ${ }^{3}$. The investigations which we have carried out show that liposomes are potentially useful as adjuvants and there is reason to believe that further modifications of the system, such as the incorporation of Bordetella pertussis, Mycobacterium tuberculosis or microbiological or chemical products known to have adjuvant activity, will further increase their usefulness in practice.

Clinical Research Centre,

A. C. Allison

G. Gregoriadis

Watford Road,

Harrow, Middlesex HAI $3 U J, U K$

Received August 19; revised September 23, 1974.

${ }^{1}$ Gregoriadis, G., and Buckland, R. A., Nature, 244, 170-172 (1973). ${ }^{2}$ Gregoriadis, G., Swain, C. P., Wills, E. J., and Tavill, A. S., Lancet, i, 1313-1316 (1974).

${ }^{3}$ Gregoriadis, G., and Allison, A. C., FEBS Lett., 44, 71-74 (1973).

${ }^{4}$ Faulk, P. W., and Houba, V., J. Immun. Meth., 3, 87-98 (1973).

\section{Differences in the effects of adult thymectomy on T-cell mediated responses in vitro}

EVIDENCE exists indicating that functionally different subsets of $\mathrm{T}$ lymphocytes are activated during the in vitro allograft response. Thus, the $\mathrm{T}$ cells responding primarily by proliferation in the mixed lymphocyte culture (MLC) may be distinct 